DOI: http://dx.doi.org/10.33846/hn50107

http://heanoti.com/index.php/hn

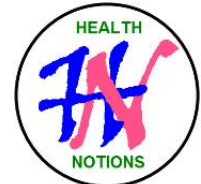

RESEARCH ARTICLE

URL of this article: http://heanoti.com/index.php/hn/article/view/hn50107

\title{
The Effectiveness of Health Education on the Motivation to Quit Smoking in the Islamic Boarding School Students in Aceh
}

\author{
Ismail Ismail $^{1(\mathrm{CA})}$, Rapitos Siddiq ${ }^{2}$, Bustami Bustami ${ }^{3}$, \\ ${ }^{1(\mathrm{CA})}$ Department of Nursing, Poltekkes Kemenkes Aceh, Indonesia; ismail@poltekkesaceh.ac.id (Corresponding \\ Author) \\ 2Department of Nursing, Poltekkes Kemenkes Padang, Indonesia; rapitos@poltekkespadang.ac.id \\ ${ }^{3}$ Department of Nursing, Poltekkes Kemenkes Aceh, Indonesia; amitihar@yahoo.co.id
}

\begin{abstract}
Introduction: The phenomenon of smoking in the pesantren shows that almost all students studying at the pesantren smoke. There is no regulation that states that smoking is prohibited and that makes them free to smoke. Sufficient knowledge about the dangers of smoking to health can motivate people to quit smoking. Motivation can be done in various ways, one of which is by using audiovisual media. Objective: To determine the effectiveness of audio-visual health education about the dangers of smoking on the motivation to quit smoking in the Islamic boarding school students in Aceh. Methods: The research design was a quasy experimental pretestposttest with control group design, involving 38 participants for the intervention group and 38 participants for the control group. Data analyzed by paired sample t-test and independent sample t-test. Results: There was no difference in the average motivation to quit smoking before the intervention group was given to the intervention group and the control group $(\mathrm{p}=0,664)$. The intervention group was more effective at increasing the students' motivation to quit smoking compared to the control group $(\mathrm{p}=0.027)$. Conclusion: Health education using audiovisuals was more effective in increasing the motivation of the students to quit smoking, so that audiovisuals can be used during health education.
\end{abstract}

Keywords: health education; audiovisual; motivation to quit smoking

\section{INTRODUCTION}

Pesantren or islamic boarding schools is one of the places to study. The learning process in pesantren does not only transfer knowledge, but also emphasizes the development of individual character. The advantages of the pesantren include helping attitude, solidarity, and brotherhood among students. However, one of the drawbacks that smoking behavior is regarded as an ordinary and reasonable ${ }^{(1)}$. However, there are drawbacks, namely the habit of group members who perceive smoking as something normal and natural.

The phenomenon of smoking in Islamic boarding schools is still common. Interviews with several santri stated that almost all santri who studied at their pesantren smoked and those who did not smoke could be counted on their fingers. In fact, there is no regulation that states that smoking is prohibited.

Smoking behavior is a public health problem because it can cause various diseases and even death ${ }^{(2)}$. Smoking can increase the risk of negative health such as hypertension, obesity, and diabetes ${ }^{(3)}$. Smoking also has an impact on psychological disorders. Smoking is bad behavior, but smokers continue the habit ${ }^{(4)}$.

Sufficient knowledge will motivate individuals to behave healthily. Smokers who are active either occasionally or every day tend to have low knowledge compared to nonsmokers ${ }^{(5)}$. A person's desire to quit smoking is caused by a person's knowledge of the dangers of smoking which is accompanied by a strong desire and motivation to do $\mathrm{so}^{(6)}$. Motivation can be done in various interesting ways to increase the interest of the intended target. Along with the times, electronic media is very possible as a medium for providing motivation, namely by using video ${ }^{(7)}$.

The use of audio visuals to increase motivation to quit smoking is more significant because it attracts someone's attention so that it arouses someone's enthusiasm for information and is also easier to accept than using print media, resulting in the average score of motivation that gets counseling using audio visual media is higher than in print media $^{(6)}$. 
The smoking behavior of students at Islamic Boarding School in Aceh is one of the things that can affect the quality of life of the students. Currently, the most frequent audio-visual interventions address only one theme of the dangers of smoking. Can interventions with different themes increase the motivation to quit smoking in students? For this reason, researchers are interested in conducting research on the effectiveness of health education on the motivation to quit smoking in the Islamic Boarding School Students in Aceh 2019.

\section{Design and Setting}

\section{METHODS}

This study used a quasy experimental with a pretest-posttest design with control group design. The population in this study ware students of Islamic Boarding School in Aceh. The sample in this study were Islamic boarding school students who smoked, which amounted to 38 participants according the inclusion criteria, namely aged 15-20 years and had been students at least 1 year. The sampling technique was done two stage. The first stage was to determine the intervention group carried out by cluster random sampling. The second stage is purposive sampling technique to determine the participants.

\section{Data Collection}

Ethical clearance was obtained from The Ethics Committee of Health Research (KEPK) of Poltekkes Kemenkes Aceh, Indonesia. Before participants were given a questionnaire and intervention, the researcher provided an explanation and gave informed consent. The data collection process was carried out by providing a questionnaire before and after the implementation of the health education model was carried out. The questionnaire was used an adaptation of previous research that has been tested for validity and reliability ${ }^{(8)}$. The number of questions given to measure the motivation to quit smoking was 42 questions in the form of a Likert scale.

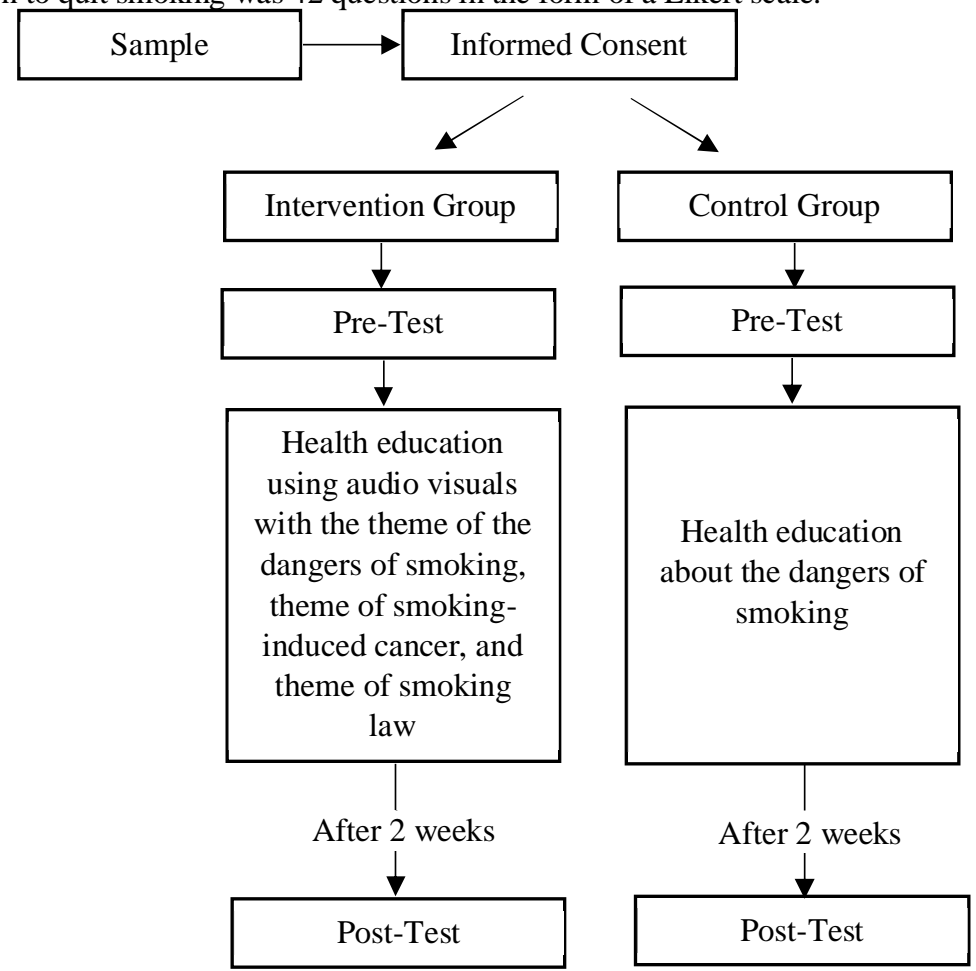

Figure 1. Data collection procedures

The intervention given to the experimental group was health education using audio visuals with the theme of the dangers of smoking, theme of smoking-induced cancer, and theme of smoking law. An audio-visual health education intervention was provided with 3 repeat video playbacks. The intervention given to the control group was health education about the dangers of smoking. Measurement of motivation to quit smoking was carried out 2 weeks after being given the intervention.

This research was conducted in 2 Islamic boarding schools, namely Madinatul Muta'allimin Islamic Boarding School as intervention group and Madinatul Fata Islamic Boarding School as control group. The research was conducted in May 2019, for 4 weeks. 


\section{Statistical Analysis}

Statistical analysis used descriptive analysis and bivariate analysis. Category data were reported as frequency and percentage. Continuous data were reported as population mean and standard deviasion (SD). This research is normally distributed, so which data analyzed by paired t-test and independent t-test.

\section{Descriptive Analysis}

\section{RESULTS}

Table 1. Distribution of age and length of being a santri (student)

\begin{tabular}{clcccc}
\hline \multirow{2}{*}{ No } & \multicolumn{1}{c}{ Characteristic } & \multicolumn{2}{c}{ Intervention } & \multicolumn{2}{c}{ Control } \\
\cline { 2 - 6 } & & $\mathrm{f}$ & $\%$ & $\mathrm{f}$ & $\%$ \\
\hline 1 & Age & & & & \\
& $\begin{array}{l}\text { Intermediate adolescent } \\
\text { (15-17 years old) }\end{array}$ & 24 & 63.2 & 17 & 44.7 \\
& $\begin{array}{l}\text { Late adolescents } \\
\text { (18-21 years old) }\end{array}$ & 14 & 36.8 & 21 & 55.3 \\
\hline 2 & Length of being a santri & & & & \\
& (student) & 4 & 10.5 & 3 & 7.9 \\
& 2 years & 16 & 42.1 & 13 & 34.2 \\
& 3 years & 12 & 31.6 & 13 & 34.2 \\
& 4 years & 6 & 15.8 & 9 & 28.9 \\
\hline
\end{tabular}

Based on table 1, it shows that the most age group of students in the intervention group was middle adolescents (15-17 years) as many as 24 students (63.2\%), while in the control group was late teens 18-21 years) as many as 21 students $(55.3 \%)$. The duration of being a student was mostly in the intervention group, namely 3 years as many as 16 students (42.1\%) as well as in the control group as many as 13 students (34.2\%).

Table 2. Distribution of motivation to quit smoking in the intervention and control group

\begin{tabular}{cccccc}
\hline Group & Motivation & Mean & Minimum & Maximum & Std. Deviation \\
\hline Intervention & Pre-Test & 86.97 & 83.00 & 91.00 & 2.22 \\
& Post-Test & 100.92 & 90.00 & 115.00 & 5.97 \\
\hline Control & Pre-Test & 86.71 & 82.00 & 92.00 & 2.97 \\
& Post-Test & 98.21 & 85.00 & 112.00 & 5.90 \\
\hline
\end{tabular}

Based on the table 2, it shows that in the intervention group that was provided with audio-visual health education, the average motivation of the students to quit smoking before the intervention was 86.97 with a standard deviation of 2.22. After being given the intervention, the average motivation of the students to quit smoking had increased. The average motivation of the students to quit smoking after the first intervention was 100.92 with a standard deviation of 5.97.

Based on the table 2, also show that in the control group that was given health education, the average motivation of the students to quit smoking before the intervention was 86.71 with a standard deviation of 2.97. After being given the intervention, the average motivation of the students to quit smoking has increased. The average motivation of the students to quit smoking after the first intervention was 98.21 with a standard deviation of 5.90 .

\section{Bivariate Analysis}

Table 3. Differences in average motivation to quit smoking before and after intervention in the intervention and control group

\begin{tabular}{|c|c|c|c|c|}
\hline \multirow{2}{*}{ Group } & \multicolumn{2}{|c|}{ Motivation $($ Mean \pm SD) } & \multirow{2}{*}{$\Delta$ Mean \pm SD } & \multirow{2}{*}{ p-value } \\
\hline & Pre-Test & Post-Test & & \\
\hline Intervention & $86.97 \pm 2.22$ & $100.92 \pm 5.97$ & $13.94 \pm 4.89$ & 0.000 \\
\hline Control & $86.71 \pm 2.92$ & $98.21 \pm 5.82$ & $11.50 \pm 4.55$ & 0.000 \\
\hline p-value ${ }^{b}$ & 0.664 & 0.050 & 0.027 & \\
\hline
\end{tabular}

a. Paired sample t-test

b. Independent sample t-test

Based on table 3, it shows that there was a significant difference in the average motivation between before and after being given an audio-visual health education intervention with $\mathrm{p}$-value $=0.000(\mathrm{p}<0.05)$. In the control 
group, it shows that there was a significant difference in the average motivation between before and after health education intervention was given with $\mathrm{p}$-value $=0.000(\mathrm{p}<0.05)$.

Before being given the intervention, there was no significant difference in the average motivation of students to quit smoking between the intervention and control groups with $p$-value $=0.664$. After being given the intervention, there was a significant difference in the average motivation of the students to quit smoking between the intervention and control groups with $\mathrm{p}$-value $=0.050$. The results of the increase in the motivation to quit smoking of the students also showed that there was a significant difference between the intervention and control groups with $\mathrm{p}$-value $=0.027$. The group with the highest increase in the motivation to quit smoking was the audiovisual health education group with the increase in value of 13.94.

\section{Characteristics of Respondents}

\section{DISCUSSION}

Adolescence is a transitional period between childhood and adulthood. During this time, there are deeper emotional changes, social changes and physical changes. According to The Health Resource and Service Administration Guidelines in the United States, the age range for adolescents is 11-21 years and is divided into three stages, namely early adolescence (11-14 years), middle adolescents (15-17 years), and late teens (18-21 years). This definition is then put together in the terminology of young people (young people) which includes ages $10-24$ years $^{(9)}$.

This research was conducted on students aged 15-21 years. The results showed that the most age group of students in the intervention group was 24 students (15-17 years), while in the control group, the late adolescents (18-21 years) were 21 students $(55,3 \%)$.

Differences in the characteristics of adolescents based on their age development. Early adolescents tend to just start developing new thoughts, one of which is curiosity about cigarettes. At this time, adolescents began to express their freedom and right to express their own opinions, were more easily influenced by their friends, experienced extraordinary physical changes, were often too confident that their emotions usually increased and resulted in difficulty accepting parental advice and direction ${ }^{(10)}$.

The results also showed that the duration of being a santri was at most in the intervention group, namely 3 years as many as 16 students (42.1\%) as well as in the control group as many as 13 students (34.2\%). The length of time being a student is assumed to be related to the students' motivation to quit smoking (see Tabel. 1).

According to research conducted at the Al Luqmaniyah Islamic boarding school in Yogyakarta, it shows that the friendship process during boarding school, weak regulations regarding smoking bans and the process of forum events where smoking is ensured in almost every activity ${ }^{(11)}$. This is what causes the number of students who smoke in the pesantren because of the habits that occur while they are in the pesantren. The influence of the environment, peers, parents and even advertisements has become a role model that influences students to smoking attitudes and behavior.

\section{Difference in the Average Motivation to Smoke Before and After the Intervention}

There was a significant difference in the mean motivation between before and after being given an audiovisual health education intervention with $\mathrm{p}$-value $=0.000(\mathrm{p}<0.05)$. Likewise, the control group showed that there was a significant difference in the average motivation between before and after the first intervention was given in the group that was given health education with $\mathrm{p}$-value $=0.000(\mathrm{p}<0.05)$.

The results also showed that before the intervention was given, there was no significant difference in the mean motivation of the students to quit smoking between the intervention and control groups with p-value $=0.664$. After being given the intervention, there was a significant difference in the average motivation of the students to quit smoking between the intervention and control groups with p-value $=0.050$. The results of the increase in the motivation to quit smoking of the students also showed that there was a significant difference between the intervention and control groups with $\mathrm{p}$-value $=0.027$. The group with the highest increase in the motivation to quit smoking was the audiovisual health education group with the increase in value of 46.94 .

This study is in line with research conducted on students of SMA 2 Purwokerto which showed that after being given health education about the dangers of smoking, the respondents' knowledge that dominates was good, namely $77.8 \%$ after being given leaflet media and $88.9 \%$ after being given video media. This shows that video media shows more percentage of good knowledge than leaflet media. However, statistically, there is no significant difference between health education with leaflet media and video media on increasing knowledge about the dangers of smoking ${ }^{(12)}$.

A person's desire to quit smoking is caused by a person's knowledge of the dangers of smoking which is accompanied by a strong desire and motivation to do $\mathrm{so}^{(6)}$. Motivation can be done in various interesting ways to increase the interest of the intended target. Video is an audiovisual media that can reveal objects and events like 
the real situation, by using video a person is able to understand learning messages more meaningfully so that the information conveyed through the video can be fully understood ${ }^{(7)}$.

According toand research institutes computer technology research (CTR), the use of media is a supporting right to achieve success in achieving health education goals. A person is able to remember up to $50 \%$ if they see and hear and are able to remember $80 \%$ if they are done at once ${ }^{(13)}$. Knowledge is dominant which is important for the formation of one's actions. Good knowledge will foster a sense of self-confidence as well as attitudes and behavior, so that it can increase motivation to be better ${ }^{(14)}$. Another factor that is thought to motivate someone to quit smoking is health. The longer a person smokes, his health will be disturbed so that the person will find it easier to quit smoking ${ }^{(15,16)}$.

A person's motivation to quit smoking is influenced by 5 interconnected subsystems, namely plans, responses, impulses and inhibitions, motives, and evaluations. The subsystem produces mental events that come and go out of life as a result of the influences in the system, together with the ever-changing matrix of stimuli and information and the whole level of it. The stimuli and information that comes from our senses and memories have a direct influence on the five subsystems so that they can motivate someone to change.

The intervention given to the intervention group was in the form of health education using audio-visuals, while in the control group it was in the form of health education only. Health education is provided using the discussion method, where students are given time to ask questions. The materials given to the two groups also used the same theme. However, the highest increase occurred in the intervention group. Researchers assume this because students can not only discuss, but can see firsthand the dangers of smoking for human organs. Unlike the case in the control group, students can only hear explanations and discuss the dangers of smoking without seeing pictures or videos about the dangers of smoking to human organs.

\section{CONCLUSION}

Health education using audiovisuals was more effective in increasing the motivation of students to quit smoking compared to groups that were only given health education $(\mathrm{p}=0,027)$. The group with the highest increase in the motivation to quit smoking was the audiovisual health education group with the increase in value of 46.94. It is hoped that health workers can use audio-visual educational media in providing education and the pesantren can improve policies to reduce smoking behavior.

\section{REFERENCES}

1. Kholili HKH. Pondok Pesantren Dan Pengembangan Potensi Dakwah. Jurnal Dakwah. 2012;13(2):177-202.

2. West R. Tobacco smoking: Health impact, prevalence, correlates and interventions. Psychology \& health. 2017;32(8):1018-1036.

3. Hu-Nyun K, Mi-Ae S, Jae-Hun R, et al. Association between cigarette smoking frequency and health factors among Korean adults. Iranian journal of public health. 2018;47(Suppl 1):19.

4. Ullah H, Iqbal U, Azhar S, Khan IU, Murtaza G. Prevalence and psychological characterization of smoking amongst university students in Abbottabad, Khyber Pakhtunkhwa, Pakistan. Tropical Journal of Pharmaceutical Research. 2015;14(11):2121-2124.

5. Al-Turkstani AHM, Alkail BA, Hegazy AA, Asiri SI. Knowledge, attitude, and practice among primary healthcare physicians toward smoking cessation in Makkah, Saudi Arabia. Int J Med Sci Public Health. 2016;5(7):1-11.

6. Kumboyono K. Analisis faktor penghambat motivasi berhenti merokok berdasarkan Health Belief Model pada mahasiswa Fakultas Teknik Universitas Brawijaya Malang. Soedirman Journal of Nursing. 2011;6:1-8.

7. Primavera IRC, Suwarna IP. Pengaruh Media Audio-Visual (Video) Terhadap Hasil Belajar Siswa Kelas XI Pada Konsep Elastisitas. 2014:

8. Putri SA. Motivasi untuk Berhenti Merokok pada Mahasiswa Perokok Berat ditinjau dari Self Efficacy dan Pengetahuan Bahaya Rokok. Program Magister Sain Psikologi Unika Soegijapranata; 2015.

9. Kusmiran E. Kesehatan reproduksi remaja dan wanita. Jakarta: Salemba Medika. 2011;21

10. Jatmika S. Genk remaja. Kanisius; 2010.

11. Abdulloh C. Internalisasi Budaya di Pesantren (Studi di Pondok Pesantren Pesantren Putra Putri Al Luqmaniyah Yogyakarta). 2018;

12. Anggraeni Y, Tresno NRIA, Susanti IH, Mangkunegara IS. The Effectiveness of Health Education Using Leaflet and Video on Students' Knowledge About the Dangers of Smoking in Vocational High School 2 Purwokerto. Atlantis Press; 2020:369-375.

13. Suiraoka IP, Supariasa IDN. Media pendidikan kesehatan. Yogyakarta: Graha Ilmu. 2012:5-7.

14. Notoatmodjo S. Promosi kesehatan dan perilaku kesehatan. Jakarta: rineka cipta. 2012:45-62.

15. Rahmah M, Huriati H, Arbianingsih A. Perbedaan efektivitas pendidikan kesehatan media Facebook dan media leaflet terhadap motivasi berhenti merokok pada remaja. Journal of Islamic Nursing. 2018;3(1):62-70.

16. Inoue-Choi M, Hartge P, Liao LM, Caporaso N, Freedman ND. Association between long-term low-intensity cigarette smoking and incidence of smoking-related cancer in the national institutes of health-AARP cohort. International journal of cancer. 2018;142(2):271-280. 